\title{
MODELI OSTVARIVANJA VEZA \\ U BIBLIOGRAFSKIM ZAPISIMA S NAGLASKOM \\ NA PRIMJENI POSEBNOG POLJA ZA POVEZIVANJE \\ INTEGRIRANOG KNJIŽNIČNOG \\ PROGRAMA ALEPH (LKR)
}

\author{
RELATIONSHIP MODELS IN BIBLIOGRAPHIC \\ RECORDS WITH AN EMPHASIS ON ALEPH SPECIAL \\ LINKING FIELD LKR
}

Ivan Miočić

Nacionalna i sveučilišna knjižnica u Zagrebu

imiocic@nsk.hr

UDK / UDC 025.3: 004.62

Stručni rad / Professional paper

Primljeno / Received: 30. 3. 2018.

Prihvaćeno / Accepted: 9. 6. 2018.

\section{Sažetak}

Cilj. Cilj je rada analizirati načine ostvarivanja veza u bibliografskim zapisima upotrebom polja za povezivanje bibliografskih zapisa iz formata MARC 21 (linking entry fields 760-787) i posebnog polja za povezivanje integriranog knjižničnog programa Aleph, s osvrtom na Integrirani knjižnični sustav Nacionalne i sveučilišne knjižnice $i$ knjižnica iz sustava znanosti i visokog obrazovanja Republike Hrvatske.

Pristup. Uz utemeljenje u stručnim izvorima raspravlja se o teorijskom i praktičnom pogledu korištenja polja za povezivanje iz formata MARC 21 te polja za povezivanje integriranog knjižničnog programa Aleph, u kontekstu i izvan konteksta sustavnog načina rada u Integriranom knjižničnom sustavu Nacionalne i sveučilišne knjižnice i knjižnica iz sustava znanosti $i$ visokog obrazovanja Republike Hrvatske. Govori se o upotrebi navedenih polja pri izvornoj katalogizaciji u bibliografskim bazama NSK01 i ZAG01

Vjesnik bibliotekara Hrvatske 61, 1(2018), 397-412

ISSN 0507-1925

(C) VBH 2018. 
te se daje kratak osvrt na njihove značajke pri preuzimanju zapisa iz bibliografske baze NSK01 u bazu ZAG01.

Rezultati. Prikazana je funkcionalnost polja za povezivanje među bibliografskim zapisima u bazama NSK01 i ZAG01 primjenom posebnog polja za povezivanje integriranog knjižničnog programa Aleph (LKR).

Originalnost/vrijednost. Rad se tematikom dotiče funkcionalnosti polja za povezivanje bibliografskih zapisa kroz prizmu bibliografskih konceptualnih modela, zbog čega se otvara prostor za razmatranje polja za povezivanje u kontekstu bibliografske organizacije u okruženju (otvorenih) povezanih podataka.

Ključne riječi: polja za povezivanje, bibliografski zapisi, MARC 21, Aleph, integrirani knjižnični sustavi

\section{Abstract}

Purpose. The aim of this paper is to analyze the methods of linking bibliographic records with the use of MARC 21 linking entry fields and special Aleph linking field LKR, with reference to the Integrated Library System of the National and University Library in Zagreb and Croatian Academic and Research Libraries.

Approach. A theoretical and practical view of the use of MARC 21 linking entry fields and Aleph special linking field LKR in and beyond the context of the Integrated Library System of the National and University Library in Zagreb and Croatian Academic and Research Libraries has been given on the basis of literature overview. The use of these fields in original cataloging in bibliographic databases NSK01 and ZAG01 has been discussed, as well as their use after record download from bibliographic database NSK01 to ZAG01.

Findings. The fully functionality of LKR links between bibliographic records in NSK01 and ZAG01 databases has been shown.

Originality/Value. The paper deals with the functionality of linking fields briefly through the context of bibliographic conceptual models, thus opening up space for consideration of linking fields in the (open) linked data environment.

Keywords: linking entry fields, bibliographic records, MARC 21, Aleph, integrated library systems

\section{Uvod - svrha i razlog povezivanja bibliografskih zapisa}

Potrebu za međusobnim povezivanjem bibliografskih zapisa treba tražiti $u$ određenim srodnostima kataložnih jedinica koje se opisuju, bilo da se radi o djelima u svescima, prijevodima i izvornicima, istim izdanjima na drugom medi- 
ju, različitim izdanjima na istom mediju itd. Pat Riva primjerice ističe kako su polja za povezivanje iz bibliografskog formata MARC 21 stvorena s namjerom da ističu određene srodnosti između različitih bibliografskih zapisa. ${ }^{1}$ Te srodnosti svoje su uporište našle i u teorijskim razmatranjima izražavanja bibliografskih odnosa predloženim u konceptualnim modelima poput FRBR-a ${ }^{2}$ ili, opširnije, aktualnog LRM-a. ${ }^{3}$ Polja za povezivanje, s druge strane, jedan su od mehanizama bibliografskih formata za izražavanje bibliografskih odnosa iz teorijskih postavki u praktičnu funkcionalnost. ${ }^{4} \mathrm{U}$ ovom radu govorit će se o poljima za povezivanje u kontekstu bibliografskog formata MARC 21, s obzirom na činjenicu da je to format koji se koristi u Integriranom knjižničnom sustavu Nacionalne i sveučilišne knjižnice i knjižnica iz sustava znanosti i visokog obrazovanja Republike Hrvatske (u nastavku rada Integrirani knjižnični sustav) te će se poseban naglasak staviti na analizu primjene posebnog polja za povezivanje LKR.

Polja za povezivanje u bibliografskom formatu MARC 21 svoje porijeklo povlače iz određenih napomena koje su se na kataložnim listićima „generirale“ kako bi korisnike kartičnih kataloga upućivale ne neki drugi kataložni listić sa zapisom za srodnu kataložnu jedinicu. Tek kada su se te napomene počele bilježiti u strojno čitljivim MARC zapisima, a koji su se potom mogli prikazivati i u mrežnom okruženju, funkcija omogućavanja strojnih poveznica postala je relevantna tema. ${ }^{5}$ Joe Altimus u svom je radu iz 1995. godine istaknuo kako se važnost polja za povezivanje sve više povećava budući da se radi o informativnim sadržajima koji korisnicima omogućuju jednostavniju navigaciju među srodnim zapisima. ${ }^{6}$ Polja su se izvorno koristila isključivo za serijske publikacije, no kada je 1982. godine odobreno i polje 773 (Host Item Entry), njihova primjena počela se ticati svih drugih formata. ${ }^{7} \mathrm{U}$ vrijeme kada su se polja za povezivanje MARC 21 počela pojavljivati ne samo u kartičnim katalozima već i u onima koje su korisnici mogli

1 Riva, P. Mapping MARC 21 linking entry field to FRBR and Tillett's taxonomy of bibliographic relationships. // Library resources \& technical services, 48, 2(2004), str. 130. Dostupno i na: https://journals.ala.org/index.php/lrts/article/view/5422 [citirano: 2018-01-16].

2 Uvjeti za funkcionalnost bibliografskih zapisa: završni izvještaj / IFLA-ina Studijska skupina za uvjete za funkcionalnost bibliografskih zapisa ; odobrio Stalni odbor IFLA-ine Sekcije za katalogizaciju; [s engleskog prevela Tinka Katić]. Zagreb: Hrvatsko knjižničarsko društvo, 2004.

3 IFLA Library Reference Model: a conceptual model for bibliographic information / Pat Riva, Patrick Le Boeuf and Maja Žumer, Consolidation Editorial Group of the IFLA FRBR Review Group. August 2017. [citirano: 2018-05-15]. Dostupno na: https://www.ifla.org/files/assets/cataloguing/frbr-lrm/ifla-lrm-august-2017.pdf.

4 Riva, P. Nav. dj., str. 130.

5 Program for Cooperative Cataloging, Standing Committee on Automation, Task Group on Linking Entries. Final report. February 2005. Str. 3. [citirano: 2018-01-20]. Dostupno na: https:// www.loc.gov/aba/pcc/sca/documents/tglnkentr-rpt05.pdf.

6 Altimus, J. Serial linking notes and MARC 760-787 fields in OPAC displays. // Advances in Serials Management, 2, (1995), str. 51.

7 Riva, P. Nav. dj., str. 131. 
pretraživati i putem mreže, dakle OPAC-ima i WebPAC-ima, sustavno se počeo ostvarivati njihov veći potencijal od onog koji im je prvotno namijenjen. Napomene s kataložnih listića postupno su se naime mogle početi koristiti i kao izravne poveznice i/ili hiperveze na zapise za srodne kataložne jedinice.

Vrijedi istaknuti kako svrha i uloga polja za povezivanje nije razjašnjena kataložnim pravilnicima, a ni taksonomije bibliografskih odnosa iz konceptualnih modela također se ne odnose ni na jedno specifično polje iz bibliografskog formata na raspolaganju. ${ }^{8}$ Do definicija polja za povezivanje i opisa njihova korištenja treba stoga doći konzultiranjem standarda za izradu strojno čitljivih zapisa, kao što je primjerice MARC 21 Format for Bibliographic Dana. ${ }^{9}$

Polja za povezivanje u bibliografskom formatu MARC 21 nalaze se u bloku $7 X X$, i to u rasponu od polja 760 do polja 787. Prema standardu MARC 21 ta polja identificiraju neku drugu srodnu kataložnu jedinicu koje je opisana posebnim zapisom. Identificiranje može biti izvršeno generiranjem napomena koje bi upućivale na postojanje zapisa za neku srodnu kataložnu jedinicu ili, prema Pat Rivi, idealnije, generiranjem i napomene i strojne poveznice. ${ }^{10}$

Prema Radnoj grupi za polja za povezivanje Kongresne knjižnice, tri su osnovne funkcije tih polja:

1. generiranje napomena

2. omogućavanje kretanja korisnicima kataloga među srodnim bibliografskim zapisima te (teorijski)

3. omogućavanje stvaranja alternativnih prikaza bibliografskih informacija koje bi korisnicima mogle biti od veće koristi pri informacijskom pretraživanju nego prikaz individualnih bibliografskih zapisa na koje upućuju napomene ili koji su povezani nedovoljno razumljivim strojnim poveznicama. ${ }^{11}$

Generiranje napomene, odnosno prikaz sadržaja polja za povezivanje u OPAC-u, definirano je odabirom indikatora. Prvi indikator može imati vrijednost 0 ili 1. Ukoliko je odabrana vrijednost 0 , polje će generirati napomenu, odnosno bit će vidljivo u WebPAC-u. Ukoliko je vrijednost prvog indikatora 1, napomena se neće generirati. Joe Altimus kao razloge za neprikazivanje polja za povezivanje kao napomene navodi dva razloga. Prvi razlog tiče se kompleksnosti veze, uslijed koje se konstantama prikaza polja za povezivanje ne može dovoljno dobro

8 Program for Cooperative Cataloging. Nav. dj., str. 3.

9 MARC format for bibliographic data. Update No. 25, December 2017. [citirano: 2018-02-03].

Dostupno na: https://www.loc.gov/marc/bibliographic/.

10 Riva, P. Nav. dj., str. 132.

11 Program for Cooperative Cataloging. Nav. dj., str. 4-5. 
objasniti vrsta, a da prikaz u WebPAC-u bude razumljiv korisniku. Zbog toga je u takvim slučajevima potrebno koristiti polje napomene 580 u kojem bi se veza pobliže razjasnila. ${ }^{12}$ Radna grupa za polja za povezivanje pak ističe kako ta praksa sprečava stvaranje redundantnih informacija, ali s druge strane zatire i cilj stvaranja hiperveza. ${ }^{13}$ Altimus kao drugi razlog ističe moguće slučajeve kada određena zbirka zapravo ne posjeduje primjerak, pa bi prema tome prikazivanje polja za povezivanje kao napomene bilo kontradiktorno. ${ }^{14}$

Vrijednost drugog indikatora u poljima 760-787 regulira pojavnost konstanti prikaza. Konstante prikaza mogu se nazvati i uvodnim riječima ili frazama koje se u WebPAC-u strojno generiraju kako bi poveznica s korisničke strane bila razumljiva. Primjerice ukoliko se na mjestu drugog indikatora kao vrijednost nalazi praznina, sustav bi prije sadržaja samog polja 760-787 morao moći generirati, u skladu s jezikom katalogizacije, standardne fraze kao što su 'Translation of', 'Translated as', 'Has supplement', 'Supplement to' itd. Vrijednost 8 na mjestu drugog indikatora blokira generiranje konstante prikaza, a podatak o vrsti veze može se alternativno navesti u potpolju \$i ukoliko je to potrebno.

Unutar funkcionalnog knjižničnog programa, polja 760-787 kao hiperveze morala bi biti jednostavna i praktična za korištenje. Potpolja tih polja definirana su kao podrška alfanumeričkom i numeričkom povezivanju. To znači da se povezivanje može odvijati pomoću tekstnog sadržaja ili putem kontrolnih brojeva i identifikatora. Povezivanje putem kontrolnih brojeva odvija se pomoću potpolja \$w, s obzirom na činjenicu da to potpolje služi za upisivanje kontrolnih brojeva zapisa. Identifikatori se bilježe u potpoljima \$x (ISSN), \$y (CODEN) te \$z (ISBN), pa se tako numeričko povezivanje zapisa može definirati i tim potpoljima. Povezivanje putem tekstnog sadržaja omogućeno je putem podataka zabilježenih u potpoljima \$a (glavna odrednica), \$s (jedinstveni stvarni naslov) te \$t (naslov). Ukoliko su polja ispravno indeksirana, povezivanje zapisa unutar bibliografskih baza, odnosno stvaranje hiperveza među njima, na takav način ne bi trebalo izazivati veće poteškoće. ${ }^{15} \mathrm{U}$ Integriranom knjižničnom sustavu MARC 21 polja $760-787$ ne funkcioniraju kao hiperveze među bibliografskim zapisima s obzirom na to da tu funkciju izvršava Alephovo posebno polje LKR. No svakako vrijedi istaknuti kako i polja za povezivanje MARC 21 mogu vršiti tu ulogu, što je primjerice bio slučaj u prethodnom sustavu Voyager $^{16}$ (slika 1 i slika 2).

12 Altimus, J. Nav. dj., str. 62.

13 Program for Cooperative Cataloging. Nav. dj., str. 16.

14 Altimus, J. Nav. dj., str. 63.

15 Riva, P. Nav. dj., str. 131.

16 Ex Libris. Voyager 7.0 system administration user's guide. June 2011. Str. 8-10. [citirano: 2018-04-15]. Dostupno na: https://systems.lib.wvu.edu/files/voyager/V_SystemAdmin_7.pdf. 


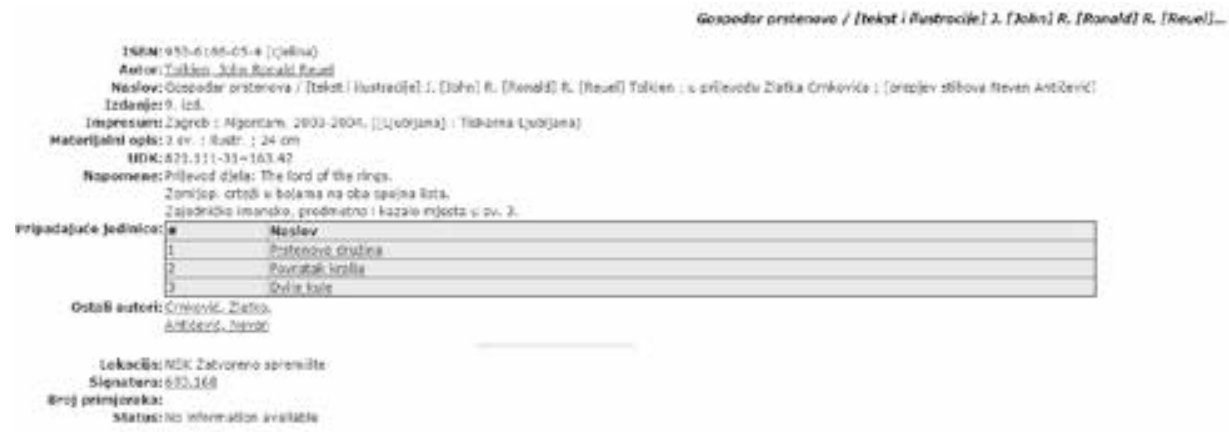

Slika 1. Zapis za djelo u svescima iz sustava Voyager; prikaz polja 774 generiranog i kao napomena i kao hiperveza

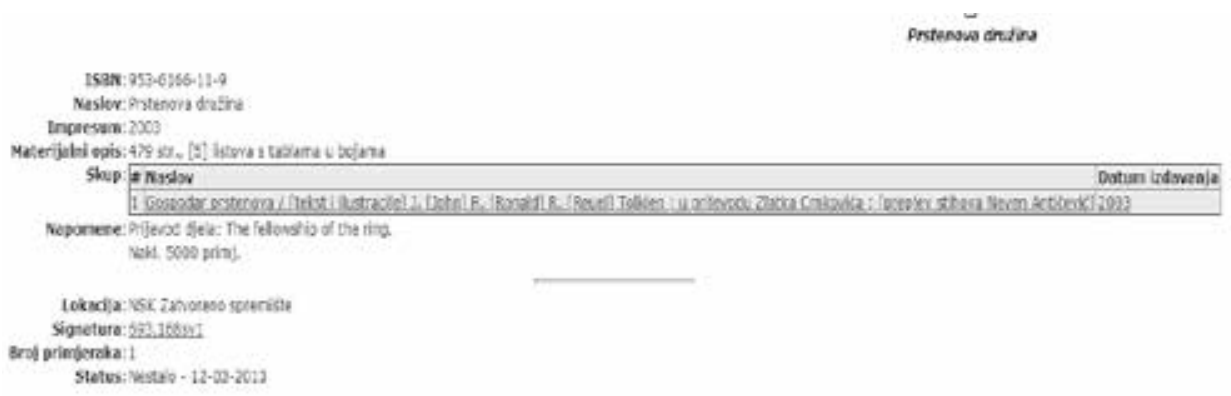

Slika 2. Zapis za svezak u kojem je izrađeno polje 774 generirano u zapisu na slici 1; povratna veza na ,gornju razinu“ izrađena je sistemski

\section{Polja za povezivanje i izražavanje bibliografskih odnosa}

MARC 21 Format for Bibliographic Records u uvodu poglavlja koje se tiče polja za povezivanje navodi tri vrste veza koje se kodiraju poljima za povezivanje. To su sljedeće vrste:

1. kronološki odnosi - vremenske veze između kataložnih jedinica, npr. između serijske publikacije i njezinih prethodnika, odnosno sljedbenika (polja 777, 780, 785)

2. horizontalni odnosi - veze između različitih oblika kataložnih jedinica po pitanju jezika, formata, medija itd. (polja $765,767,775,776$ ) 
3. vertikalni odnosi - hijerarhijski odnosi cjeline naspram dijelova te odnosi dijelova naspram cjeline kojoj pripadaju, npr. veze članka i pripadajućeg mu časopisa, veze među višerazinskim zapisima ili veze jedinice građe i nakladničke cjeline u kojoj je jedinica objavljena (polja 760, $770,772,773,774) \cdot{ }^{17}$

Pat Riva navodi kako se ta podjela prvi put pojavljuje 1977. godine u bibliografskom formatu UNIMARC te objašnjava kako je ona služila mnogim katalogizatorima, ali i sistemskim dizajnerima, kao sažeti uvod u bibliografske odnose, posebice po pitanju serijskih publikacija. Ukoliko polja za povezivanje 760-787 razmatramo u kontekstu bibliografskih odnosa predstavljenih u konceptualnim modelima FRBR ili aktualnijem LRM-u, a koji u teorijskom aspektu osuvremenjuju kretanje i navigaciju knjižničnim katalozima, tada se postavlja pitanje koliko bibliografski odnosi mogu bit reprezentativni poljima 760-787, posebice u suvremenom informacijskom okruženju koje stremi prema semantičkom webu. Pat Riva u svom radu Mapping MARC 21 Linking Entry Fields to FRBR and Tillett's Taxonomy of Bibliographic Relationships ističe kako su polja za povezivanje iz formata MARC 21 veliki mehanizam za izražavanje odnosa između bibliografskih zapisa. ${ }^{18}$ Tom Delsey primjerice ističe kako polja 770 i 772 mogu izražavati odnose work-to-work, odnos expression-to-expression može se pojaviti u poljima 765, 767 i 775, manifestation-to-manifestation u 760, 762, 773, 774 i 776 itd. $^{19}$ Međutim ako uzmemo u obzir taksonomije bibliografskih odnosa predstavljene u modelu FRBR, a proširene u LRM-u, ili pak taksonomije Barbare T. Tillett ${ }^{20}$ ili Richarda P. Smiraglie ${ }^{21}$, ispostavlja se da se nijedna od tih taksonomija ne referira na neko specifično MARC-polje. ${ }^{22}$ Pat Riva nakon provedenog mapiranja polja 760-787 i taksonomija Barbare B. Tillett i FRBR-a primjećuje npr. problematiku mapiranja polja 775 (Other edition entry ${ }^{23}$ ) u kojem se prema standardu MARC 21 kodiraju tri vrste drugih izdanja: language editions, regular-print reprints te other editions. Međutim polje 775 ne posjeduje indikatore kojima bi se te tri vrste

\footnotetext{
17 MARC format for bibliographic data. Nav. dj.

18 Riva, P. Nav. dj., str. 130-132.

19 Delsey, T. Functional analysis of the MARC 21 bibliographic and holdings formats. Network Development and MARC Standards Office, 2002. Str. 7. [citirano: 2018-02-03]. Dostupno na: https://www.loc.gov/marc/marc-functional-analysis/source/analysis.pdf.

20 Više o taksonomiji u Tillett, B. A taxonomy of bibliographic relationships. // Library Resources \& Technical Services 35, 2(1991), 150-158.

21 Više o taksonomiji u Smiraglia, R. P. Derivative bibliographic relationships: linkages in the biblbiographic universe. // Navigating the networks : proceedings of the ASIS mid-year meeting, Portland, Oregon, May 21-25, 1994. / eds. Deborah Lines Andersen, Thomas J. Galvin, Mark D. Giguere. Medford : ASIS, 1994. Str. 167-183.
}

22 Riva, P. Nav. dj., str. 133.

23 MARC format for bibliographic data. Nav. dj. 
drugih izdanja jasnije definirale te na taj način tijekom mapiranja preklopile s taksonomijom predloženom u FRBR-u. Vrste izdanja iz polja 775 tijekom teorijskog redizajna kataloga ne bi bilo jednostavno izraziti odgovarajućim tipovima odnosa iz FRBR-a, kao što su revision, translation, reproduction ili alternate, budući da bez odgovarajućeg indikatora u polju 775 ništa zapravo ne bi govorilo o tome o kakvoj se vrsti izdanja radi. Kao konačan rezultat lako bi se mogla nametnuti nedovoljno dorečena funkcija navedenog polja u potpuno eferbeeriziranom knjižničnom katalogu. Pat Riva sličnu situaciju primjećuje i kod polja 770 standarda MARC 21, koje također ne posjeduje indikatore kojima bi se napravila razlika između njegove dvojake uloge has supplement/special issue.

Kada je riječ o izražavanju odnosa kroz bibliografski format MARC 21, autorice Paula Picco i Virginia Ortiz Repico u svom radu The Contribution of FRBR to the Identificaton of Bibliographis Relationships objašnjavaju kako se u formatu MARC 21 odnosi mogu izraziti kroz određena polja napomena, poput 500, 501, 502, 505 ili 525, ali posebno ističu kako su upravo polja za povezivanje 760-787 najkorisnija za izražavanje odnosa između bibliografskih zapisa. Međutim autorice kao veliki nedostatak kod reprezentativnosti bibliografskih odnosa kroz format MARC 21 ističu korištenje isključivo tekstualnih mehanizama za izražavanje odnosa, a koje pak „mogu interpretirati jedino ljudi budući da se oslanjaju na riječi“ ${ }^{24}$ Autorice nadalje zaključuju kako struktura formata MARC 21 ne dopušta neku drugu mogućnost povezivanja zapisa ${ }^{25}$, ako se funkcionalnost tih polja primjerice sagledava u kontekstu semantičkog weba. Prethodno smo u radu objasnili kako potpolja 760-787 jesu definirana kao podrška i alfanumeričkom i numeričkom povezivanju. Međutim numeričko povezivanje funkcionalno je na razini formata, ali ne i izvan formata. Također vrijedi spomenuti kako polja 760-787 ne podržavaju dodjeljivanje jedinstvenog identifikatora URI-a, a čija bi dodjela pak omogućila da bibliografske informacije iz tih polja budu sistemski ,shvaćene te prema tome i automatski procesirane.

\section{Polja za povezivanje u bibliografskim bazama Integriranog knjiž- ničnog sustava}

U Integriranom knjižničnom sustavu postoje dvije bibliografske baze u kojima se odvijaju procesi katalogizacije. To su baza NSK01 koju koriste samo i jedino katalogizatori Nacionalne i sveučilišne knjižnice te baza ZAG01 koju koriste katalogizatori (ostalih) sastavnica Integriranog knjižničnog sustava. Katalogizacija

24 Picco, P.; V. Ortiz Repiso. The contribution of FRBR to the identification of bibliographic relationships: the new RDA-based ways of representing relationships in catalogs. // Cataloging \& Classification Quaterly 50, 5-7(2012), 634-636. DOI: https://doi.org/10.1080/01639374.201 2.680847.

25 Isto. 
jedinica građe odvija se $u$ jednoj od navedenih baza, a ako se primjerice zapis preuzima iz baze NSK01 u bazu ZAG01, tada podatke koji se odnose isključivo na bazu NSK01 treba zamijeniti podacima svojstvenima bazi ZAG01 (npr. kontrolni broj zapisa, identifikator kontrolnog broja zapisa, oznaka baze itd.). Nove podatke potrebno je unijeti ručno, ukoliko nisu postavljeni tako da se generiraju automatizmom.

Bibliografski je format koji se u Integriranom knjižničnom sustavu koristi dakle MARC 21, a programsku podršku osigurava integrirani knjižnični program Aleph, proizvod tvrtke Ex Libris. S obzirom na korištenje Alepha, veze među bibliografskim zapisima u bibliografskim bazama NSK01 i ZAG01 Integriranog knjižničnog sustava ne ostvaruju se putem polja za povezivanje formata MARC 21, već posredstvom posebnog Alephova polja LKR, koje automatizmom osigurava dvosmjernu navigaciju među povezanim zapisima (slika 3 i slika 4 prikazuju ostvarene hiperveze između bibliografskih zapisa posredstvom Alephova polja LKR). Ipak, korištenje polja 760-787 u Integriranom knjižničnom sustavu obvezno je budući da se na takav način osiguravaju veze među zapisima u mogućem okruženju van Alepha. Drugim riječima, ukoliko bi se, teorijski govoreći, zapisi iz Alepha migrirali u neki drugi sustav, sve veze iz LKR-polja bilo bi potrebno mapirati u polja 760-787. Primjerice Ex Librisov suvremeniji knjižnični program Alma, uvjetno rečeno nasljednik Alepha, pri migraciji zapisa iz svog prethodnika prema osnovi pravilno izrađenog LKR-polja automatski izrađuje polja za povezivanje iz formata MARC. Veze među bibliografskim zapisima u sustavu Alma ostvaruju se naime upravo standardiziranim MARC-poljima za povezivanje. Iz LKR-potpolja \$a (ukoliko nije prisutno potpolje $\$ r$ ili nije izrađeno u skladu sa standardom) kreiralo bi se određeno polje 760-787, potpolja $\$$ b i \$1 mapirala bi se u 760-787 potpolje \$w, potpolje \$n mapiralo bi se u potpolje naslova $\$$ t itd. ${ }^{26}$ Autorice Betsy Simpson, Jimmie Lungren i Tatiana Barr u radu Linking print and electronic books korištenje lokalnog polja van MARC-standarda, referirajući se na Alephovo polje LKR, nazivaju primjerice „gerilskom“ katalogizacijom s obzirom na to da se ne radi o standardnom polju. ${ }^{27}$ No to je polje koje i nema primarnu funkcionalnost zamijeniti standardizirana polja za povezivanje iz MARC-formata.

26 Ex Libris. Aleph to Alma migration guide. Str. 18-22. [citirano: 2018-04-15]. Dostupno na: https://knowledge.exlibrisgroup.com/Alma/Implementation_and_Migration/Migration_Guides/ ILS_Migrations/Aleph_to_Alma_Migration_Guide.

27 Simpson, B.; J. Lundgren; T. Barr. Linking print and elentronic books: one approach. // Library Resources \& Technical Services 51, 2(2011), 146-152. Dostupno i na: https://journals.ala.org/ index.php/lrts/article/view/5291/6448 [citirano: 2018-01-18]. 


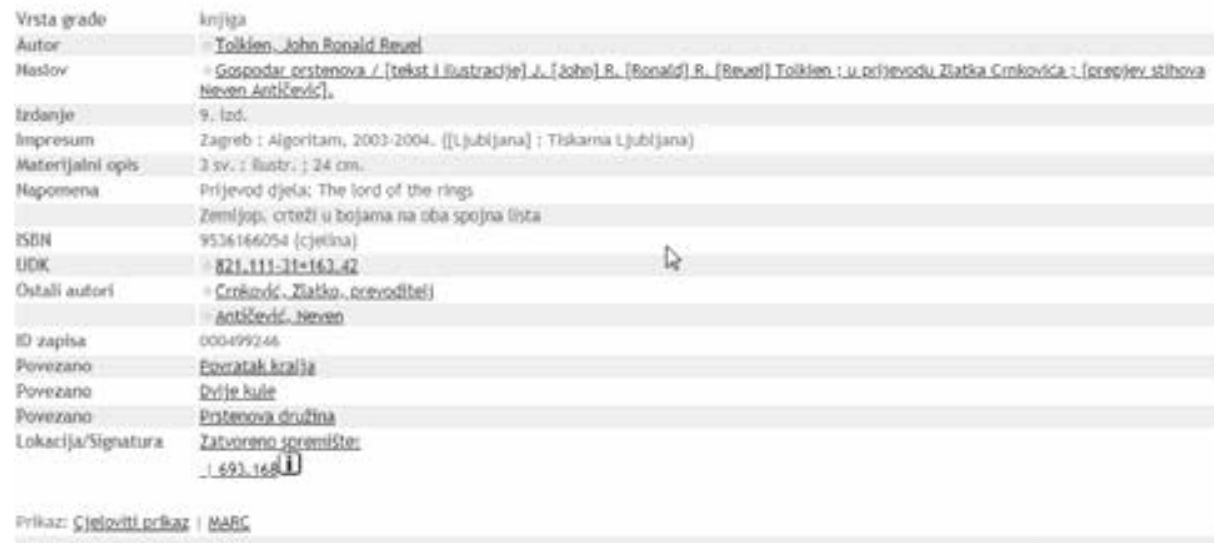

4 Prethodini zeopis ajeseci zepts *

Slika 3. Zapis za djelo u svescima u sustavu Aleph; prikaz polja LKR generiranog kao poveznica i djelomična napomena

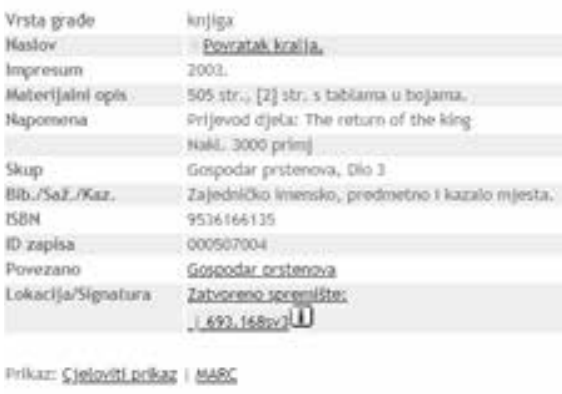

Slika 4. Zapis za svezak u kojemu je izrađeno polje LKR generirano u zapisu na slici 3; povratna veza na „gornju razinu“ sistemski je izrađena; polje 774 generirano je kao napomena

U Integriranom knjižničnom sustavu postoje određena pravila koja se moraju poštivati pri izradi polja 760-787. Već smo ranije spomenuli kako se povezivanje zapisa poljima 760-787 odvija na razini potpolja čiji je sadržaj tekstne ili numeričke prirode. U bibliografskim bazama NSK01 i ZAG01 pravilo je da se u poljima 760-787 uz sadržaj potpolja \$t obavezno unosi i potpolje \$w čiji sadržaj 
čini identifikator kontrolnog broja zapisa iza kojeg slijedi kontrolni broj s devet znamenki ${ }^{28}$, npr.

\$w (HR-ZaNSK)000919623

ili

\$w(HR-ZaZAG)000565113.

Točno je da polja 760-787 kao hiperveze funkcioniraju i prema tekstnom sadržaju iz potpolja \$t. No izglednije je da će sustavu biti jasnije što točno treba povezati ako ulogu povezivanja vrši i nekakav broj. To može biti primjerice ISSN ili, jednostavno, kontrolni broj zapisa. U bazama NSK01 i ZAG01 ne postoje dva zapisa koji dijele isti kontrolni broj pa će, prema tome, prema numeričkom sistemu povezivanja sustav pouzdanije „znati“ koje zapise treba povezati, radije nego da se „oslanja“ na podudaranje teksta između sadržaja potpolja \$t određenog polja 760-787 i sadržaja potpolja \$a polja 245 komplementarnog zapisa. Standing Committee on Automation u završnom izvještaju o relevantnosti korištenja polja za povezivanje MARC 21, objavljenu 2005. godine, zaključuje da bi zapisi trebali imati neku vrstu „standardnog broja“ unesena u prikladno potpolje pojedinog polja za povezivanje, kako bi sustav mogao izraditi hipervezu s minimalnom intervencijom katalogizatora ili, u idealnom slučaju, bez ikakve intervencije katalogizatora. ${ }^{29}$ Potpolje $\$$ w namijenjeno kontrolnom broju zapisa prema kojem se veza upućuje dobro obavlja tu funkciju ukoliko je sadržaj ispravno unesen, no ipak je potreban katalogizator koji bi taj kontrolni broj i unio u potpolja $\$ \mathrm{w}$.

Struktura polja LKR, kada je riječ o izradi veza među zapisima, u Integriranom knjižničnom sustavu jest sljedeća:

$$
\begin{aligned}
& \$ a-\text { vrsta veze } \\
& \$ b-\text { sistemski broj vezanog zapisa } \\
& \$ 1 \text { - baza u kojoj se nalazi vezani zapis } \\
& \begin{array}{l}
\$ \mathrm{~m} \text { - napomena o vezi prema dolje (sadržaj polja } 245 \text { \$a zapisa koji se } \\
\text { povezuje) }
\end{array} \\
& \begin{array}{l}
\$ \mathrm{n} \text { - napomena o vezi prema gore (sadržaj polja } 245 \text { \$a komplementarnog } \\
\text { zapisa) }
\end{array} \\
& \begin{array}{l}
\$ \mathrm{r}-\text { veza s MARC-poljem. }
\end{array}
\end{aligned}
$$

\footnotetext{
28 Radi se zapravo o sadržaju polja 035 komplementarnog zapisa (035 \$a(HR-ZaNSK)000919623), a čiji se sadržaj pak sistemski generira iz polja 001 (kontrolni broj) i 003 (identifikator kontrolnog broja).

29 Program for Cooperative Cataloging. Nav. dj., str. 16-17.
} 
Kod ostvarivanja veza među zapisima Alephovim poljem LKR važno je imati na umu kako se ono unosi samo u jedan zapis. Povratna veza izrađuje se sistemski. Vrste Alephovih veza koje se u Integriranom knjižničnom sustavu koriste jesu:

1. UP - veze prema gore na drugi bibliografski zapis ${ }^{30}$

2. PAR - usporedna veza među bibliografskim zapisima

3. ANA - istovremena veza između dva bibliografska zapisa i jedinica građe ${ }^{31}$

4. HOL - veza između bibliografskog zapisa i zapisa o posjedovanju

5. ADM - veza između bibliografskog i administrativnog zapisa.

Veze među zapisima pomoću polja LKR mogu se izrađivati ručno (user generated) ili sistemski (system generated). Sistemski izrađene veze povezuju administrativne zapise ${ }^{32}$ iz administrativnih baza NSK50 i ZAG50 s bibliografskim zapisima. Veze između zapisa o posjedovanju (holding baze NSK60 i ZAG60) i bibliografskih zapisa također se izrađuju sistemski. Polje LKR, koje se tako nalazi u jednoj od administrativnih baza, sistemski je generirano polje, i to u trenutku izrade zapisa o primjerku. U potpolju \$a generira se vrsta veze ADM, u potpolju \$b istovjetni kontrolni broj bibliografskog zapisa iz bibliografske baze NSK01 ili ZAG01 te u potpolju \$1 oznaka baze prema kojoj je veza upućena (u ovom slučaju bibliografska baza NSK01, odnosno ZAG01). Polje LKR koje se nalazi u zapisu o posjedovanju u holding bazama NSK60 i ZAG60 također je generirano sistemski, $\mathrm{i}$ to $\mathrm{u}$ trenutku izrade novog zapisa o posjedovanju. U potpolju \$a generira se vrsta veze HOL, u potpolju \$b kontrolni broj bibliografskog zapisa iz bibliografske baze NSK01 ili ZAG01, a u potpolju \$1 oznaka baze prema kojoj je veza upućena (u ovom slučaju bibliografska baza NSK01, odnosno ZAG01).

Ostale vrste veza iz LKR-potpolja \$a, UP, PAR i ANA izrađuju se ručno. Važno je istaknuti kako su te veze u korelaciji s poljima za povezivanje MARC 21, pa se tako veza UP u Integriranom knjižničnom sustavu izrađuje u zapisima koji sadrže polja 760 i 774, veza PAR u zapisima koji sadrže polja 765, 772, 775, 776 i 787, dok se veza ANA izrađuje u zapisima koji sadrže polje 773.

Sistemski broj povezanog zapisa, koji stoji u definiciji potpolja \$b, u kontekstu Integriranog knjižničnog sustava sistemski je generirani kontrolni broj koji se nalazi u prvom varijabilnom MARC 21 polju 001. U Integriranom knjižničnom sustavu kontrolni broj MARC 21 sistemski se generira iz posebnog Alephova po-

\footnotetext{
30 UP-veza sistemski generira povratnu vezu DN na zapisu s kojim se veza ostvaruje.

31 U Integriranom knjižničnom sustavu veza ANA koristi se za povezivanje analitičkih jedinca s matičnim publikacijama.

32 Zapisi za primjerke vezani su uz administrativne (ADM) zapise.
} 
lja sistemskog broja SYS ${ }^{33}$, što ne znači da se MARC 21 polje 001 ne može kreirati i nekom drukčijom strukturom od Alephova sistemskog broja. U generiranom obliku kontrolni broj ručno se prenosi u potpolje \$b polja LKR i mora biti istovjetan s kontrolnim brojem koji je upisan u potpolje \$w određenog polja 760-787. Program tijekom kreiranja poveznice „pamti“ sadržaj potpolja \$b polja LKR, tj. kontrolni broj, te u bibliografskoj bazi, ovisno o tome odvija li se katalogizacija u bazi NSK01 ili ZAG01, pronalazi njegov par u polju 001 odgovarajućeg zapisa s kojim se veza ostvaruje.

Potpolje \$1 služi za bilježenje bibliografske baze u kojoj se veza ostvaruje. Ukoliko se zapis izrađuje u bazi NSK01, u potpolju \$1 polja LKR mora biti navedena baza NSK01, a isto tako, ukoliko se zapis izrađuje u bazi ZAG01, u potpolju \$1 mora biti upisana baza ZAG01. Na takav način program će ,znati““ kako par kontrolnom broju upisanu u potpolje \$b mora tražiti u polju 001 odgovarajućeg zapisa koji se nalazi ili u bazi NSK01 ili ZAG01. U Integriranom knjižničnom sustavu čest je slučaj preuzimanja zapisa iz baze NSK01 u bazu ZAG01, gdje se mora izvršiti izmjena određenih podataka. U LKR-polju kontrolni broj zapisa preuzetog iz baze NSK01 mora biti zamijenjen kontrolnim brojem iz baze ZAG01 te, shodno tomu, u potpolju $\$ 1$ mora biti navedena ispravna baza u kojoj se nova veza ostvaruje, dakle ZAG01. Ukoliko bi se primjerice u potpolju \$b nalazio kontrolni broj zapisa iz baze ZAG01, a u potpolju \$1 greškom ostala oznaka baze NSK01, tada bi sustav zapis koji se sad nalazi u bazi ZAG01 povezao sa zapisom u bazi NSK01, jer je takvu naredbu i dobio. Takvim unakrsnim povezivanjem između dviju bibliografskih baza u vezu se mogu dovesti dvije potpuno različite kataložne jedinice, a što bi s korisničke strane značilo potpunu irelevantnost rezultata pretraživanja u WebPAC-u.

Potpolja \$m i \$n generiraju se sistemski i njihov sadržaj nije dopušteno unositi ručno, kako bi se smanjila stopa pogrešno kodiranih podataka. Sadržaj potpolja \$m generira se iz potpolja \$a polja 245 zapisa u kojem se izrađuje polje LKR, dok se sadržaj potpolja \$n generira iz potpolja \$a polja 245 komplementarnog zapisa. Nakon generiranja potpolja \$m i \$n, ono što je uz njih poželjno ručno dodati jest sadržaj potpolja \$h iz polja 245 komplementarnog zapisa. Primjerice ako se radi o povezivanju istog izdanja u različitim medijima, sustav pri generiranju potpolja \$m u polju LKR neće povući i podatak koji se nalazi u potpolju \$h zapisa za primjerice elektroničko izdanje. Ručnim dodavanjem sadržaja tog potpolja poveznica će u prikazu na WebPAC-u jasnije precizirati o kakvu se zapravo drugom mediju radi.

Potpolje \$r u prikazu poveznice na WebPAC-u dodatno pojašnjava vrstu veze, ostvarene poljem LKR, ali prema standardu formata MARC 21. Koristeći potpo-

33 Ex libris. Aleph system librarian's guide - cataloging, Version 20. March 2012. Str. 538. [citirano: 2018-02-03]. Dostupno na: https://knowledge.exlibrisgroup.com/Aleph/Product_Documentation/04_Version_20. 
lje \$r sistemski se, za prikaz u WebPAC-u, generiraju uvodne riječi prije sadržaja potpolja \$n ili \$m. ${ }^{34}$ Uvodne riječi koje se generiraju u hipervezi nastaloj pravilno izrađenim poljem LKR u sukladnosti su s onima koje definira standard MARC 21. Također vrijedi istaknuti kako tijekom mapiranja veza iz LKR-polja u polja 760-787 sadržaj potpolja \$r može uvjetovati stvaranje standardiziranog polja za povezivanje MARC 21. Primjerice pri migraciji podataka iz sustava Aleph u sustav Alma standardizirano polje za povezivanje iz MARC-formata stvara se iz potpolja $\$ r$ ako ono postoji te ako je u sukladnosti sa standardom ${ }^{35}$.

\section{Zaključak}

Ostvarivanje veza među zapisima u Integriranom knjižničnom sustavu omogućeno je posebnim Alephovim poljem LKR. Veze su dvosmjerne i u potpunosti su funkcionalne te se može reći kako LKR u Integriranom knjižničnom sustavu izvršava svoju tehničku funkciju. Svojstvo mogućnosti sistemskog generiranja velika je prednost LKR-a. Polje se sistemski generira kada je riječ o povezivanju administrativnih zapisa i zapisa o posjedovanju s bibliografskim zapisima. Ostvarivanje takvih veza među različitim bazama nije primjerice moguće provesti standardiziranim MARC-poljima. No kako bibliografski konceptualni modeli, koji veliki naglasak stavljaju na odnose, pa i semantički potencijal knjižničnih kataloga, bivaju implementirani u kataložne standarde i formate, bibliografske bi odnose, posebice one zabilježene u obliku hiperveza, kao uvjet omogućavanja navigacije sustavom, a time i otkrivanja novog znanja, bilo izglednije izražavati kroz standardizirana polja formata. Ipak, uz daljnje osuvremenjivanje integriranog knjižničnog programa Aleph, polje LKR i dalje bi moglo služiti kao tehnička podrška za izražavanje bibliografskih odnosa, primjerice u kontekstu (otvorenih) povezanih podataka.

\section{LITERATURA}

Altimus, J. Serial linking notes and MARC 760-787 fields in OPAC displays. // Advances in Serials Management 2, (1995), 49-65.

Delsey, T. Functional analysis of the MARC 21 bibliographic and holdings formats. Network Development and MARC Standards Office, 2002. [citirano: 2018-02-03]. Dostupno na: https://www.loc.gov/marc/marc-functional-analysis/source/analysis. pdf.

34 Ex Libris. How to create links between BIB records. January 2012. Str. 7. [citirano: 2018-0203]. Dostupno na: https://knowledge.exlibrisgroup.com/Aleph/Product_Documentation/How To_Documents/Cataloging

${ }_{35}$ Ex Libris. Aleph to Alma migration guide. Nav. dj. 
Ex Libris. Aleph to Alma migration guide. Str. 18-22. [citirano: 2018-04-15]. Dostupno na: https://knowledge.exlibrisgroup.com/Alma/Implementation_and_Migration/ Migration_Guides/ILS_Migrations/Aleph_to_Alma_Migration_Guide.

Ex libris. Aleph system librarian's guide - cataloging. Version 20. March 2012. [citirano: 2018-02-03]. Dostupno na: https://knowledge.exlibrisgroup.com/Aleph/Product_Documentation/04_Version_20

Ex Libris. How to create links between BIB records. January 2012. [citirano: 2018-0203]. Dostupno na: https://knowledge.exlibrisgroup.com/Aleph/Product_Documentation/How_To_Documents/Cataloging

Ex Libris. Voyager 7.0 System Administration User's Guide. December 2008. [citirano: 2018-04-15]. Dostupno na: https://systems.lib.wvu.edu/files/voyager/V_SystemAdmin_7.pdf.

IFLA Library Reference Model: a conceptual model for bibliographic information / Pat Riva, Patrick Le Boeuf and Maja Žumer, Consolidation Editorial Group of the IFLA FRBR Review Group. August 2017. [citirano: 2018-05-15]. Dostupno na: https:// www.ifla.org/files/assets/cataloguing/frbr-lrm/ifla-lrm-august-2017.pdf.

Lee, S.; E. K. Jacob. An integrated approach to metadata interoperability. // Library Resources \& Technical Services 55, 1(2011), 17-32.

MARC 21 format for bibliographic data. Update No. 25. December 2017. [citirano: 2018-02-03]. Dostupno na: https://www.loc.gov/marc/bibliographic/.

Picco, P.; V. Ortiz Repiso. The contribution of FRBR to the idetification of bibliographic relationships: the new RDA-based ways of representing relationships in catalogs. // Cataloging \& Classification Quaterly 50, 5-7(2012), 622-640. DOI: https://doi.org/ 10.1080/01639374.2012.680847.

Program for Cooperative Cataloging, Standing Committee on Automation, Task Group on Linking Entries. Final report, February 2005. [citirano: 2018-01-20]. Dostupno na: https://www.loc.gov/aba/pcc/sca/documents/tglnkentr-rpt05.pdf.

Riva, P. Mapping MARC 21 linking entry fields to FRBR and Tillett's taxonomy of bibliographic relationships. // Library Resources \& Technical Services 48, 2(2004), 130-143. Dostupno i na: https://journals.ala.org/index.php/lrts/article/view/5422 [citirano: 2018-01-16].

Simpson, B.; J. Lundgren; T. Barr. Linking print and elentronic books: one approach. // Library Resources \& Technical Services 51, 2(2011), 146-152. Dostupno i na: https://journals.ala.org/index.php/lrts/article/view/5291/6448 [citirano: 2018-01$18]$.

Smiraglia, R. P. Derivative bibliographic relationships: linkages in the biblbiographic universe. // Navigating the networks : proceedings of the ASIS mid-year meeting, POrtland, Oregon, May 21-25, 1994. / eds. Deborah Lines Andersen, Thomas J. Galvin, Mark D. Giguere. Medford : ASIS, 1994. Str. 167-183. 
Tillett, B. A taxonomy of bibliographic relationships. // Library Resources \& Technical Services, 35, 2(1991), 150-158.

Uvjeti za funkcionalnost bibliografskih zapisa: završni izvještaj / IFLA-ina Studijska skupina za uvjete za funkcionalnost bibliografskih zapisa ; odobrio Stalni odbor IFLA-ine Sekcije za katalogizaciju; [s engleskog prevela Tinka Katić]. Zagreb: Hrvatsko knjižničarsko društvo, 2004. 